\title{
Erratum to: Flora biodiversity change detection: a case study
}

\author{
Nooshin Mardani · Jamal Ghoddousi · Shayda Mardani
}

Published online: 13 June 2014

(C) Springer Science+Business Media Dordrecht 2014

\section{Erratum to: Environ Dev Sustain (2013) 15:1271-1279 DOI 10.1007/s10668-013-9438-0}

Unfortunately, there is a typographical mistake with the family name of the first and third authors, which has been corrected in this erratum.

The online version of the original article can be found under doi:10.1007/s10668-013-9438-0.

N. Mardani $(\bowtie)$

Young Researchers Club and Elite, Takestan Branch, Islamic Azad University, Takestan, Iran e-mail: n.mardani@tiau.ac.ir

J. Ghoddousi

Soil Conservation and Watershed Management Research Institute, Tehran, Iran

S. Mardani

M.A. in Health Services Management, Science and Research Branch,

Islamic Azad University, Tehran, Iran 